This is an open access article under the CC BY-NC-ND license (https://creativecommons.org/licenses/by-nc-nd/3.0/) Issue III, November 2020

ISSN 2707-9481

ISBN 978-601-323-207-2

https://doi.org/10.31643/2020.007

\author{
Kemelbek B. E. \\ Academy of the Civil Aviation, Almaty, Kazakhstan \\ E-mail: kemelbek97@bk.ru \\ ORCID ID: 0000-0003-4464-808X
}

\title{
To the problem of increasing fuel efficiency of civil aircraft
}

\begin{abstract}
One important advantage of more efficient routes and aircraft is reduced fuel consumption and reduced emissions. As the impact of aviation on the climate is of increasing concern with the projected doubling of the number of flights worldwide to 60 million per year by 2030, efficiency will increasingly determine not only the speed of movement of passengers or goods around the world, but also the quality of the world itself. Reliable access to air transport services is a key factor contributing to social and economic prosperity throughout the world. Fundamental to this reliability are the related aspects of the safety and effectiveness of air navigation services, which are thus the main strategic priorities for ICAO. This article discusses new methods for improving the fuel efficiency of an aircraft during operation, based on reducing the time of ground operation of aircraft engines, reducing the take-off weight of aircraft, and selecting optimal piloting modes.
\end{abstract}

Keywords: fuel efficiency, methods, flight level, technical and economic evaluation of methods, tankering.

Cite this article as: Kemelbek B. E. (2020), Bolaşaq pedagog-psïxologtardıñ käsibï dayarlığınıñ erekşelikteri [To the problem of increasing fuel efficiency of civil aircraft], Challenges of Science. Issue III, 2020. Pp.: 47-51.

https://doi.org/10.31643/2020.007

Кемелбек Б. Е.

Азаматтық Авиация Академиясы, Алматы, Қазақстан

E-mail: kemelbek97@bk.ru

ORCID ID: 0000-0003-4464-808X

\section{Азаматтық ұшақтардың отын үнемдеу тиімділігін арттыру мәселесі}

\begin{abstract}
Абстракт: Әуе кемелерінің бір маңызды артықшылығы неғұрлым тиімді бағыттар мен отын шығынын төмендету және эмиссияны қысқарту болып табылады. әлемдегі ұшу санының болжамды екі еселенуіне байланысты 2030 жылға қарай жылына 60 млн. Дейін ұшу тасымалдары жүргізілсе, авиацияның климатқа әсері алаңдаушылық туғызатындықтан, тиімділік бәрінен де жолаушылар мен тауарларды әлем бойынша өткізу жылдамдығын ғана емес, сондай-ақ әлемнің өзінің сапалы жағдайын да анықтайды. Авиакөлік қызметтеріне сенімді қол жеткізу бүкіл әлемде әлеуметтік және экономикалық өркендеуге ықпал ететін негізгі фактор болып табылады. Осы сенімділік үшін қағидатты маңызы аэронавигациялық қызмет көрсетудің қауіпсіздігі мен тиімділігінің ұштасқан аспектілері бар, олар осылайша ИКАО үшін негізгі стратегиялық басымдықтар болып табылады. Берілген мақалада әуе қозғалтқыштарының жердегі жұмыс уақытын қысқартуға, әуе кемесінің ұшу салмағын азайтуға және ұшудың оңтайлы режимдерін таңдауға негізделген жұмыс кезінде азаматтық авиацияның отын тиімділігін арттырудың жаңа әдістері қарастырылды. Мақалада жанармай үнемдеудің жаңа әдістерінің экономикалық тиімділігін бағалау нәтижелері мен эксперименттік мәліметтер келтірілген.
\end{abstract}

Түйін сөздер: отынның тиімділігі, ұшу деңгейі, техникалық және экономикалық бағалау, танкерлеу.

Кіріспе. Авиацияның қазіргі замандағы маңызды бағыты реактивті отын шығынын азайту болып табылады. Әуе кемелерінің отын тиімділігін арттырудың өзектілігі планетадағы мұнай өнімдерінің (реактивті отын) шектеулі ресурстарына байланысты болып табылады. XX ғасырдың екінші жартысында, жанармай дағдарысына байланысты, көмірсутегі бағасы күрт көтерілген кезде, отын шығындарының пайызы жұмыс істейтін жолаушылар ұшағының жалпы құнының 30-35\% орнына 60-65\% жетті. Осыған байланысты әуекомпаниялардың ұшақтары азырақ тиімді бола бастайды, бұл әуе билеттерінің бағасының өсуіне және нәтижесінде жолаушылар ағынының 
төмендеуіне әсер етеді. Мәселенің шешімін екі бағытта қарастыруға болады. Біріншісі - жаңа, неғұрлым үнемді авиациялық жабдықты құруды және отын-энергетикалық ресурстарды үнемдеу мақсатында сериялық жабдықтарды түрлендіруді қамтамасыз ету үшін жобалық технологияларды жетілдіру. Екінші әдіс - әуе кемелерін жаппай пайдалану жағдайында реактивті отынның құнын төмендету. Бұл мақалада азаматтық авиацияның нақты жағдайларында реактивті отын құнын төмендетудің кейбір жолдары мен әдістері қарастырылады.

Ұшу-қону жолағына дейін жүргізу үшін пайдаланылатын реактивті отынның шығыны ұшу басталғанға дейін және қонғаннан кейінгі жүргізудегі жалпы отынның орташа есеппен 2-4\% немесе шамамен 22 минутты құрайды. Бұл көрсеткіш ауада аз уақытын өткізетін, қысқа қашықтықтағы ұшақтар үшін көбірек болып есептеледі. Қозғалтқыштарды өшіргеннен кейінде тынымсыз жұмыс жасайтын әуежайларда кідіріс болуы мүмкін, сол себептен бөлінген уақыт аралығында көрсетілген ұяшыққа жетіп үлгермейді. Жердегі қозғалтқыштың жұмыс уақытын едәуір қысқарта отырып, оның тозуын және қозғалтқыштың ауа-газ жолына бөгде заттардың түсу ықтималдығын азайту арқылы қозғалтқыш ресурстарын үнемдеуге болады [1].

Әуе кемелерін шығырмен жабдықталған жүк көлігімен тарту арқылы мәселені белгілі бір дәрежеде шешуге болады. Әуе кемесін тарту әр түрлі жағдайларда қажет болып табылады: ішкі және халықаралық рейстер әртүрлі терминалдар жүзеге асырлған жағдайда, ал әуе кемесінің келуі бір терминалға, ал екіншісінен ұшуға болады: әуе кемесі келгеннен кейін ұзақ мерзімді техникалық қызмет көрсету нысанын қажет етуі мүмкін, бұл жағдайда әуе кемесін арнайы тұраққа тарту керек, әуе кемесін жолақтан тұтқыр топыраққа түсіргенде тарту керек және басқа жағдайларда шығырмен жабдықталған жүк көлігімен тарту қажеттілігі туындайды.

Мұндай жағдайларда әуе көлігінің шассиіне арнайы жетекті орнату мәселенің перспективті шешімі ретінде қарастырылады.

Borealis Exploration компаниясының салмағы 136 кг болатын WheelTug құрылғысының бейнесі 1- суретте көрсетілген. Бұл құрылғы алдыңғы дөңгелектеріне орнатылған және екі индукциялық электр қозғалтқышындай күш береді.

Сурет 1- WheelTug типті қозғалтқышы

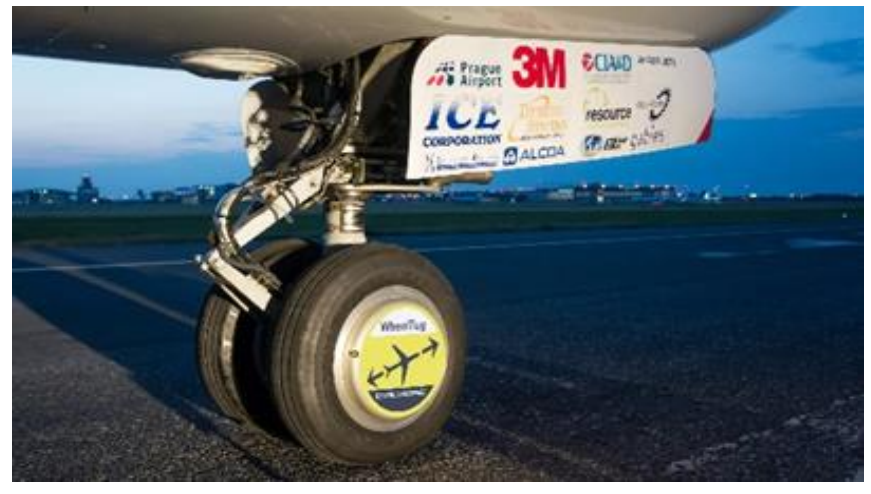

Сурет 2 - Taxibot автоматты тартқышы

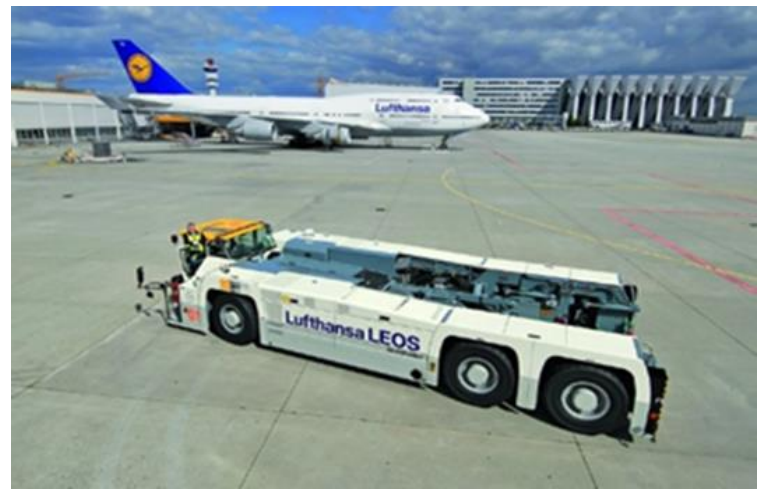

Өндірушілердің айтуынша, құрылғыны Франкфурт әуежайында қысқа фюзеляжды лайнерлерде сынақтар өткізіліп, нәтижесінде отын шығыны тәулігіне 44 тоннаға азайды [2].

Мәселені шешудің ерекше нұсқасын Airbus, Lufthansa Technik және аэродромдық тартқыштарды өндіру жөніндегі компаниямен бірлесіп Israel Aerospace Industries (IAI) ұсынды. TLD компаниясы ұшақ кабинасынан басқарылатын "автоматты тартқыш" ойлап тапты ( сурет. 2).

Бұл әдістерді олардың экономикалық тиімділігі бойынша бағалаған жөн. WheelTug Exploration әзірлеуші фирмасының 2013 жылғы жылдық экономикалық есебіне сәйкес [3] WheelTug лизинг есебінен 28 ай ішіндегі төлемі 25000 \$ құрайды. Лукойл фирмасының ТC-1 маркалы авиакеросин бағасы 1 тоннасы үшін 822, 172 \$ құрайды.

Статистикалық мәліметтерге сәйкес жердегі авиақозғалтқыштардың орташа жұмыс уақыты 32 минутты құрайды (ұшу және қону кезінде). WheelTug бағдарламасының мақсатты ұшағы Воеіпд-737 болып табылады, оның "кіші газ" режимінде отынның сағаттық шығыны> жерде 11 кг/мин құрайды. Осы құрылғыны пайдалана отырып, жанармай шығынын әр рейс үшін 352 кг-ға үнемдеуге болады. Тарфюзеляжды Boeing-737 үшін күнделікті рейстер санын 4-ке тең деп қабылдап, күніне 1408 кг немесе айына 42240 кг тең отын шығынын күнделікті үнемдеуді аламыз, жанармай бағасы 1 т үшін 822,172 \$ болса, айына 34728, 55 \$ шамасында үнемдеуді құрайды. 
Арнайы жетекпен жабдықталған ұшақ салмағының қосымша ұлғаюына байланысты, отын шығынының біршама ұлғаюын да бағалауға болады. Ұшу массасының 1 кг-ға өзгеруі кезінде отын шығынының $\mathrm{G}_{\mathrm{t}}$ өзгеруін қарастырайық.

Р-тартылыс (Н)

$$
G_{t}=P \times C_{p}
$$

$\mathrm{C}_{\mathrm{p}}$-отынның меншікті шығыны (кг/Нхс), егер

онда

$$
P=m_{0} g / K
$$

$$
G_{t}=\Delta P \times C_{p}=\Delta m_{0} \times g \times 1000 \times C_{p} / K
$$

$\mathrm{K}=15,0$ деп есепке алсак, $\mathrm{Cp}=0.06$ г $/ \mathrm{Hxc}$, онда

$$
\Delta G_{t}=1 \times 9,8 \times 1000 \times \frac{0,08}{15,0}=39,2 \Gamma
$$

Егер бір жолаушылар ұшағының жылдық ұшуын 2500 тең деп қабылдаса, 1 кг-ға салмағының артуынан отын тұтынудың жылдық ұлғаюы шамамен 100 кг құрайды. Салмағы 136 кг болатын WheelTug құрылғысының қосымша жылдық отын тұтыну көрсеткіші: 13600 кг немесе ақшалай баламада 11181,54 \$, яғни айына 932 \$ құрайды. Осылайша, лизинг есебімен жалпы ақша шығындары Ш=25000\$+932\$=25932\$. Салыстырмалы экономикалық тиімділігі төмендегі формуламен анықталады [4].

$$
\ni_{1}=\frac{\Pi}{3}=\frac{34729}{25932}=1,33
$$

Жоғарыда көрсетілгендей, ұшақтың ұшу салмағының төмендеуі, егер бір жолаушы ұшағының жылдық ұшуын 2500 сағатқа тең деп қабылдайтын болса, онда ұшақ салмағының 1 кг-ға азаюына байланысты авиаотынды тұтынудағы жылдық үнемдеу 100 кг-ға жуықталады.

Пайдаланылатын ұшақтың ұшу массасын салонның интерьерін оңтайландыру арқылы төмендетуге болады. Массаны едәуір төмендетудің негізгі тәсілі креслолардың салмақ сипаттамаларын жақсарту болып табылады. Кресло массасының 1 кг-ға төмендеуін қамтамасыз ете отырып, 100 креслосы бар ұшақ отынының жылдық шығынын 10 т-ға төмендетуге қол жеткізуге болады. Орындықтың массасын төмендету міндеті бір қарағанда қажетсіз болып көрінуі мүмкін, өйткені беріктілігі және салмағы жөнінен басқа сипаттамаларына да креслоларды әзірлеушілер орындықтың ыңғайлылығы мен сыртқы түріне назар аударуға міндетті. Austrian Airlines Recaro эконом-кластағы ұшақтарға салмағы алдыңғыларға қарағанда 3 кг-ға аз болатын 4650 креслоларды сатып алып, шамамен 6975000\$ инвестициялады. Келесі 3-суретте Recaro креслоларының бейнесі көрсетілген.

Сурет 3- Recaro креслолары

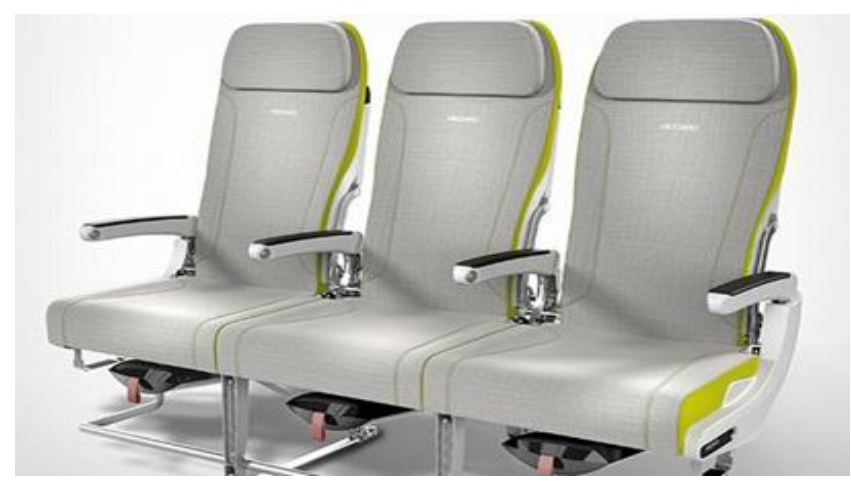

Осылайша, үнемделген масса 4650x3=13950 кг=1395 т. құрайды. Жоғарыда көрсетілгендей, бұл 13950x100=31395000кг=1395 т отынды жылдық үнемдеуге әкеледі, бұл 1 т үшін 822,2 \$ авиа отынының бағасы кезінде құрайды.

$1395 \times 822,2=1146969 \$$. 
Салыстырмалы экономикалық тиімділік

$$
\ni_{3}=\frac{\Pi}{3}=\frac{1146969}{6975000}=0,164
$$

Экономикалық тиімділіктің төмендігі мен өтелімділіктің ұзақ мерзімі туралы жайлылық деңгейін сақтау кезінде креслолар массасын төмендету мәселесі бір он жылдан бері шешіліп келеді.

Бұл мәселе өте мұқият пысықталуда және осы бағыттағы жаңа серпіліске қол жеткізу қиындау болып табылады. Алайда, бұл жалпы ұшақтың пайдалану массасын азайту проблемасының маңыздылығын төмендетпейді. Мысалы, ұшақ кабинасынан салмағы 50 кг-ға жететін қағаз құжаттамаларының орнына жалпы бағасы 1000\$ болатын, салмағы 680 граммдық 2 планшетке ауыстыру арқылы айтарлықтай үнемдеуге қол жеткізуге болады. Ұшақтың пайдалану массасының 50 кг-ға төмендеуі отынның 50 кг х $100=5$ т жылдық үнемдеуге әкеледі, бұл 1 т үшін 822,2 \$ авиа отынының бағасы кезінде құрайды.

$5 \times 822,2=4111 \$$.

Бұл ретте салыстырмалы экономикалық тиімділік

$$
\ni_{4}=\frac{\Pi}{3}=\frac{4111}{1000}=4,1
$$

Ұшақты төмендету режимдерінің оңтайлылығы. Ұшақтың отын тиімділігін арттыруға ұшу процесін оңтайландыру арқылы қол жеткізуге болады. Тұрақты төмендеумен ұшу профилі (CDO) ең тиімді болып табылады, себебі әуе қозғалысын тиісті ұйымдастыру кезінде ол ең төменгі энергетикалық шығындар тұрғысынан оңтайлы режимде төмендетуге мүмкіндік береді. Әуежай аймағында әуе кеңістігін пайдалану жүйесін дамытудың кез келген тұжырымдамасы мынадай талаптарға сәйкес келуі тиіс:

a) ұшу қауіпсіздігі және қоршаған ортаны қорғау;

б) өткізу қабілеттілігі және қолжетімді болуы;

CDO енгізуге байланысты перспективалық бағыттар мыналар болып табылады:

a) әуежай кеңістігін пайдаланудың тиімділігін арттыру;

б) ұшу траекториясының келісу дәрежесін арттыру;

в) пилот пен диспетчерге жұмыс жүктемесін және радиобайланыс көлемін азайту;

г) отын тиімділігін арттыру және экологиялық пайда.

Төмендеу профилі мынандай бөлімдерден тұрады: абсолюттік биіктік бойынша өз беткейлерімен қалаған нүктеде ұшуды аяқтауға және тұйықталған траекторияның бойымен жылдамдыққа ие болуға, траекторияда қалу үшін қажетті, тартуды оңтайландыратын, абсолюттік биіктікті арттыруға мүмкіндік беретін шағын газ режиміндегі төмендеуден және төмендеу учаскелерінен тұрады. Ұшақ түрі және оның нақты салмағы, метеорологиялық сипаттамалары (атмосфералық қысым, жел жылдамдығы, ауа температурасы және т.б.) сияқты факторлар тік траекторияның оңтайлы бұрышына әсер етеді [5].

Сурет 4 - Прагадағы отынды үнемдеу диаграммасы, (кг)

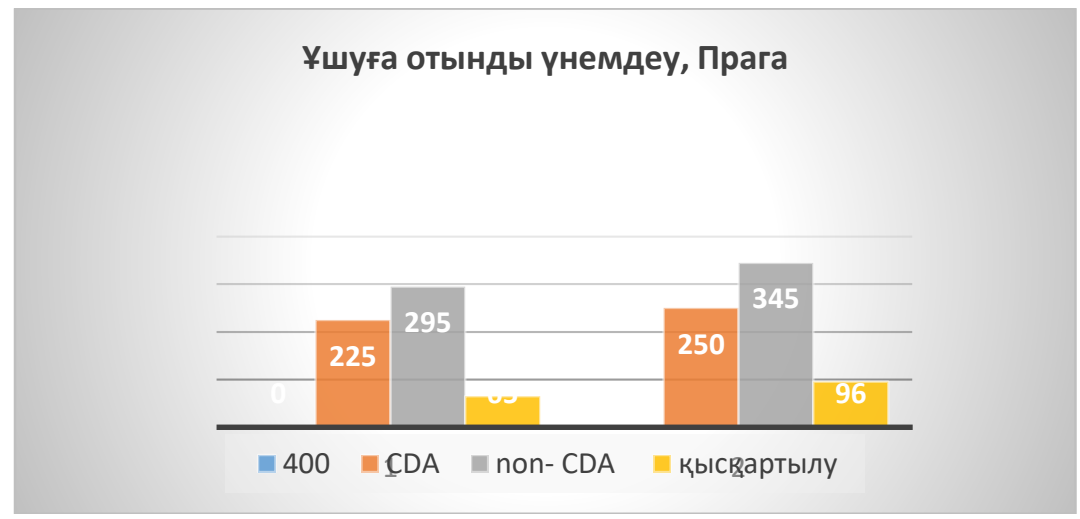

CDO пайдалануға енгізу нәтижесінде қол жеткізген экологиялық пайда мысалдары:

Әлемнің әр түрлі әуежайларында тұрақты төмендеу (CDO) режимінде ұшу өндірісін енгізу отынды үнемдеу және парниктік газдар эмиссиясын төмендету (ПГ) жоспарында айтарлықтай пайда 
әкеледі. Еуропада егжей-тегжейлі зерттеулер мен ұшу сынақтары негізінде CDO енгізу кезінде айтарлықтай үнемдеу болатындығын көрсетті. Прагада 65-96 кг отын және әрбір ұшуға $\mathrm{CO}_{2}$ эмиссиясы 200-300 (А320 және A321 әуе кемелері үшін) мөлшерінде бағаланады. Бұл потенциалды үнемдеу 1400 т отын және 4600 т $\mathrm{CO}_{2}$ эмиссиясына сәйкес келеді. Кореяда CDO нүктедегі Қосылу жүйесі негізінде ұшу үшін орташа 16\% отынның үнемделуін қамтамасыз етеді, бұл Инчхон халықаралық әуежайына әрбір ұшып келу есебінен отын шығысының 62,0 кг (200 кг $\left.\mathrm{CO}_{2}\right)$ төмендеуіне сәйкес келеді [6]. Бұдан басқа, ұшуларды болжау деңгейі артты және ӘҚБ диспетчерлеріне жұмыс жүктемесі айтарлықтай төмендеді,бұл жағдай туралы хабардарлықты және қызмет көрсету сапасын жалпы жақсартуға әкелді (4 сурет).

Табыс тарихын көрсетіп отырғандай, мұндай ұшулардың артықшылықтары маңызды болуы мүмкін. Дегенмен, қазіргі уақытта әлемде CCO / CDO енгізу деңгейі ең аз болып қалуда. Барлық мемлекеттер өздерінің мүдделі тараптарымен консультацияларда ұшулардың тиімділігін арттыру және авиацияның қоршаған ортаға әсерін төмендету мақсатында PBN пайдалана отырып, ССО және CDO енгізу мүмкіндігін анықтау үшін әуеайлақтың әуе кеңістігінде ұшуларды бағалауға тиіс болып табылады.

Қорытынды. CDO-ны сынау және енгізу нәтижелері бойынша келіп түскен деректер пайдаланылатын профильге, кеңістіктің деңгейіне байланысты отындық тиімділікті арттыру мүмкіндіктері туралы айтады. Еуропалық азаматтық авиация конференциясына (ЕКГА) қатысушымемлекеттердің ықпалында CDO -ның әлеуетті үнемділігі 50 кг-нан 150 кг-ға дейінгі аралықтағы ұшу [7, 8], бұл жыл сайынғы қаржы шығындарын 100 млн. евродан артық үнемдеумен тең болып табылады. Осылайша, авиатасымалдаушылардың авиаотын пайдалану шығындарын төмендетудің кейбір жолдары қарастырылды. Оларды еңсеру тәсілдерінің алуан түрлілігі осы проблеманы шешудегі аяқталмауын және оны ең маңызды зерттеудің қажеттілігін көрсетеді.

Мақалаға сілтеме: Кемелбек Б. Е. (2020),Азаматтық ұшақтардың отын үнемдеу тиімділігін арттыру мәселесі. Challenges of Science. Issue III, 2020. P.: 47-51. https://doi.org/10.31643/2020.007

\section{Қолданылған әдебиет тізімі}

[1]. Вовк В. И., Липин А. В., Саранский Ю. Н. Зональная навигация : учеб. пособие. СПБ. : Академия ГА, 2004. 145 с.

[2]. Самолет едет, двигатели стоят [электронный ресурc]. URL: http://aviaglobus.ru2013-01-05-5144

[3]. URL:http://wheeltug.gi/reports/FY2013_plc_annual_report_2013pdf

[4]. Паламарчук А.С. Экономика предприятия: учебник. М.: ИНФРА-М, 2013,451с.

[5]. Грэм Уорвик (6 Мая 2016). "Проблемы Аэрокосмической Отрасли Еще Предстоит Решить". Неделя Авиации И Космической Техники .

[6]. Paul Peeters (15 Ноября 2017). Влияние туризма на изменение климата и задачи по его смягчению: как туризм может стать "климатически устойчивым" Канд. пед.наук. Ту-Делфт. с. 187.

[7]. Kenzhaliev B.K., Kul'deev E.I., Luganov V.A., Bondarenko I.V., Motovilov I.Y., Temirova S.S. (2019). Production of Very Fine, Spherical, Particles of Ferriferous Pigments from the Diatomaceous Raw Material of Kazakhstan. Glass and Ceramics, 76(5-6), 194-198. https://doi.org/10.1007/s10717-019-00163-w

[8]. Doc 10013. Эксплуатационные возможности уменьшения расхода топлива и эмисии. 1-е изд. Монреаль: ИКАО, 2014.

\section{Refrences}

[1]. Vovk V. I., Lipin A. V., Saranskiy YU. N. Zonal'naya navigatsiya: ucheb. posobiye. SPB.: Akademiya GA [Zonal navigation: textbook. allowance. SPB: Academy of Civil Aviation], 2004. 145 s.

[2]. Samolet yedet, dvigateli stoyat [The plane is traveling, the engines are not working], [elektronnyy resurs]. URL: http://aviaglobus.ru2013-01-05-5144

[3]. URL:http://wheeltug.gi/reports/FY2013_plc_annual_report_2013pdf

[4]. Palamarchuk A.S. Ekonomika predpriyatiya: uchebnik [Business Economics: a textbook]. M.: INFRA-M, 2013,451s.

[5]. Grem Uorvik (6 Maya 2016). "Problemy Aerokosmicheskoy Otrasli Yeshche Predstoit Reshit'". Nedelya Aviatsii I Kosmicheskoy Tekhniki [Problems of the Aerospace Industry Still to be Solved." Aviation and Space Technology Week].

[6]. Paul Peeters (15 Noyabrya 2017). Vliyaniye turizma na izmeneniye klimata i zadachi po yego smyagcheniyu: kak turizm mozhet stat' "klimaticheski ustoychivym" [The impact of tourism on climate change and the challenges of mitigating it: how tourism can become "climate resilient"]. Cand. ped.nauk. Tu-Delft. s. 187.

[7]. Kenzhaliev B.K., Kul'deev E.I., Luganov V.A., Bondarenko I.V., Motovilov I.Y., Temirova S.S. (2019). Production of Very Fine, Spherical, Particles of Ferriferous Pigments from the Diatomaceous Raw Material of Kazakhstan. Glass and Ceramics, 76(5-6), 194-198. https://doi.org/10.1007/s10717-019-00163-w

[8]. Doc 10013. Ekspluatatsionnyye vozmozhnosti umen'sheniya raskhoda topliva i emisii. 1-ye izd. Monreal': IKAO [Operational Opportunities for Reducing Fuel Consumption and Emission. 1st ed. Montreal: ICAO], 2014. 